\title{
Evaluation of Chemical Signatures in the Developmental Stages of Mischocyttarus consimilis Zikán (Hymenoptera, Vespidae) Employing Gas Chromatography Coupled to Mass Spectrometry
}

\author{
Michelutti, K. B.;* Cardoso, C. A. L.; Antonialli-Junior, W. F.
}

Rev. Virtual Quim., 2017, 9 (2), 535-547. Data de publicação na Web: 10 de fevereiro de 2017

\section{http://rvq.sbq.org.br}

\begin{abstract}
Avaliação da Assinatura Química dos Estágios de Desenvolvimento de Mischocyttarus consimilis Zikán (Hymenoptera, Vespidae) Empregando Cromatografia Gasosa Acoplada à Espectrometria de Massas
\end{abstract}

Resumo: Tanto os hidrocarbonetos presentes na cutícula das vespas sociais, quanto o material do ninho têm compostos que são responsáveis por mediar as interações entre indivíduos dentro de suas colônias. Sabe-se que cada estágio de desenvolvimento desde o ovo até o adulto tem sua própria composição química cuticular. Contudo, nenhum estudo com este tema foi feito com uma vespa social do gênero Mischocyttarus, assim, o objetivo deste estudo foi avaliar, a variação da composição química cuticular de todos os estágios de desenvolvimento e do material do ninho da vespa social Mischocyttarus consimilis por CG-EM. Como resultado, foram identificados 109 compostos na cutícula e no material do ninho, sendo que 79 são da classe dos alcanos ramificados, 20 dos alcanos lineares, 9 de alcenos e 1 ácido graxo. Cada estágio tem sua própria composição química epicuticular. Durante a progressão dos estágios de desenvolvimento há uma redução no numero de alcanos lineares e aumento de alcanos ramificados. Essas mudanças devem ocorrer por conta das funções desempenhadas pelas diferentes classes de compostos durante cada estágio.

Palavras-chave: Ninhos; Assinatura Química; Variação Intraespecífica; Vespas Sociais.

\section{Abstract}

Both the hydrocarbons present in the cuticle of social wasps, as the material of the nest have compounds that are responsible for mediating the interactions between individuals within their colonies. It is known that each developmental stage from egg to adult has its own cuticular chemical composition. However, no studies regarding this subject was performed with social wasps of the genus Mischocyttarus, thus, the aim of this study was to evaluate the variation of cuticular chemical composition of all developmental stages and nest of the social wasp Mischocyttarus consimilis by GCMS. As a result, 109 compounds were identified in the cuticle and nest material, 79 branched alkanes, 20 linear alkanes, 9 alkenes and 1 fatty acid. Each stage has its own epicuticular chemical composition. During the progression of developmental stages there is a reduction in number of linear alkanes and an increase in branched alkanes. These changes may occur due to the roles played by the different classes of compounds during each stage.

Keywords: Nests; Chemical Signature; Intraspecific Variation; Social Wasps.

\footnotetext{
* Universidade Estadual de Mato Grosso do Sul (UEMS), Laboratório de Ecologia Comportamental (LABECO), CEP 79804-970, Dourados-MS, Brazil.

Mkamylla michelutti@yahoo.com.br

DOI: 10.21577/1984-6835.20170031
}

Rev. Virtual Quim. |Vol 9| | No. 2| |535-547| 


\section{Avaliação da Assinatura Química dos Estágios de Desenvolvimento de Mischocyttarus consimilis Zikán (Hymenoptera, Vespidae) Empregando Cromatografia Gasosa Acoplada à Espectrometria de Massas

\author{
Kamylla B. Michelutti, ${ }^{a} *$ Claudia Andrea L. Cardoso, ${ }^{b}$ William Fernando \\ Antonialli-Junior $^{\mathrm{a}}$ \\ a Universidade Estadual de Mato Grosso do Sul, Laboratório de Ecologia Comportamental \\ (LABECO), CEP 79804-970, Dourados-MS, Brazil. \\ ${ }^{b}$ Universidade Estadual de Mato Grosso do Sul, Centro de Pesquisa em Biodiversidade (CPBIO), \\ CEP 79804-970, Dourados-MS, Brasil. \\ * kamylla michelutti@yahoo.com.br
}

Recebido em 8 de março de 2016. Aceito para publicação em 10 de fevereiro de 2017

\section{Introduction \\ 2. Experimental \\ 3. Results and discussion \\ 4. Conclusions}

\section{Introduction}

The body of insects is covered by a cuticle composed of different layers. The outermost layer, called epicuticle, ${ }^{1}$ is composed of hydrocarbons, alcohols, alkyl esters, sterols, and aldehydes. ${ }^{2}$ Hydrocarbons are generally the main compounds, particularly linear alkanes, branched alkanes, and alkenes. ${ }^{3}$ These compounds primarily act as a barrier against dehydration ${ }^{1}$ and as water repellents in the nest, keeping it dry. ${ }^{4}$

Another important function of epicuticular hydrocarbons is their role as chemical signals in communication, especially in social insects. ${ }^{5}$ They can vary in quantity and quality according to species, age, sex, and colony. ${ }^{3}$ Chemical communication is used by most social insects. ${ }^{6}$ When these compounds are involved in intraspecific communication, they are known as surface pheromones. ${ }^{7}$ Using these compounds social wasps, popularly known as marimbondo, are able to distinguish the offspring and adults of their colony from those of alien colonies. ${ }^{8-10}$ It is therefore clear that there is intraspecific variation of these compounds, which may be caused by genetic ${ }^{8,11,12}$ or environmental factors. ${ }^{11,12}$

Insects use epicuticular hydrocarbons to discriminate between colony members at all developmental stages, because since the egg stage there are distinct chemical profiles. ${ }^{13}$ These profiles are important for providing adult wasps with information concerning the 
individuals or stages of development with which they interact. ${ }^{8}$

In colonies of Vespula vulgaris (Linnaeus, 1758) the epicuticular hydrocarbons of the eggs are partly originated from the female ovipositor. ${ }^{14,15}$ The eggs pass through the oviduct, where glands release compounds that act as markers of this stage. ${ }^{16}$ Larvae and pupae also have distinctive profiles that change in their composition according to the stage, ${ }^{4}$ as observed in the species Vespula germanica (Fabricius, 1793). The larvae of Polistes dominula (Christ, 1791) possess a characteristic chemical pattern that is distinct from that of the adults. ${ }^{10}$ Adults of Mischocyttarus consimilis (Zikán, 1949) have unique cuticular chemical profiles whose composition is only completed 4-5 days after emergence, following social interactions and contact with the nest itself. ${ }^{17}$

The chemical compounds responsible for intraspecific interactions in social insects are present in a system of signals, with the nest itself playing an important role. ${ }^{10,13}$ Some studies have described the relationship between the compounds present in the individuals and the nest. ${ }^{4,13,18}$ The nests of the P. dominula wasp, the characteristic profile of the epicuticular hydrocarbons of the colony was maintained intact for at least one year. ${ }^{19}$ During this period, the founders returned to their natal nests before starting their colonies, in order to regain the signature that had been preserved by the nest. ${ }^{19}$ It is therefore clear that the nest itself plays a central role in the recognition system. ${ }^{20}$ Nonetheless, there is also evidence that recently emerged adults and pupae of $P$. dominula do not use nest signals as the main reference for recognition among individuals. ${ }^{21,22}$

The analysis of epicuticular compounds of insects is usually performed after extraction with hexane $e^{4,5,9,13}$ by gas chromatography, which is the most widespread technique among researchers in this area. ${ }^{4,5,9-13}$ There are few studies that have evaluated the evolution of epicuticular chemical composition of social wasps during the different developmental stages, ${ }^{4,8-10,13}$ or that have evaluated the relationship between the compounds present in adults and nest. ${ }^{4,8,13,18,19,21,22} \quad M$. consimilis is a Neotropical social wasp, previously restricted to Paraguay, but now also found in the south of Mato grosso do Sul and west of Paraná. ${ }^{23-25}$ Therefore, this is the first study with the Mischocyttarus genus to test the hypothesis that there is a pattern of changes in chemical composition during the course of the developmental stages. It was also investigated whether there is a relationship between the nest and the compounds present in the cuticle of immature and adult individuals.

\section{Experimental}

Four colonies of $M$. consimilis in postemergence phase were collected in Dourados, Mato Grosso do Sul, Brazil (2213'16"S; 5448'20"W). All colonies were removed from the nesting sites in the evening by placing a plastic container around the nest and then detaching the stem peduncle from the substrate.

Social wasps of this species present four stages of development, egg, larva, pupa and adult, and the larval stage is divided into five larval instars. ${ }^{26}$ After collection, all stages of insect development: eggs, larvae, pupae, and adults were killed by freezing and then individually placed in Eppendorf vials, with subsequent storage in a freezer at $-20{ }^{\circ} \mathrm{C}$. In order to confirm the larval instar, the head capsule of each larva was measured with the aid of a stereo microscope (model S6D, Leica) coupled to an ocular micrometer and then the instars were analyzed and confirmed by Dyar's rule. ${ }^{27}$ The first and last (fifth) larval instars were used to identify changes in the chemical composition of the larval stage.

The chemical composition of each nest was determined by analysis of a sample with an area of $1 \mathrm{~cm}^{2}$ extracted from the central cells of the nest. For analysis of epicuticular compounds, extractions were made using 3 whole individuals of all stages (egg, first and 
last instar larvae, pupa and adult) and the entire sample removed from the nest. The cuticular components of each sample were extracted by immersion in a glass container with $2 \mathrm{~mL}$ of hexane (HPLC grade, Tedia) for 2 min, adapted from. ${ }^{28}$ After filtration, the solvent was removed in an exhaustion chapel. Each extract was then dissolved in $100 \mu \mathrm{L}$ of hexane prior to chromatographic analysis. Hexane was analyzed under the same conditions used for the samples in order to assess possible contamination. All experiments were performed in triplicate.

The analyses were performed using a gas chromatography (GC-2010 Plus, Shimadzu, Kyoto, Japan) equipped with a mass spectrometer detector (GC-MS Ultra 2010), employing a fused silica DB-5 capillary column, (30m length $\times 0.25 \mathrm{~mm}$ diameter, $0.25 \mu \mathrm{m}$ film thickness, 5\% phenyl, 95\% dimethylpolysiloxane; J\&W, Folsom, California, USA). The carrier gas was helium

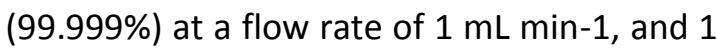
$\mu \mathrm{L}$ of sample volume was injected in splitless mode. The initial oven temperature was 100 o C, followed by a ramp to $300^{\circ} \mathrm{C}$ at a rate of 3 ${ }^{\circ} \mathrm{C}$ min-1 and remaining at $300{ }^{\circ} \mathrm{C}$ for $20 \mathrm{~min}$. The injector, detector, and transfer line temperatures were kept at $280{ }^{\circ} \mathrm{C}$. The detector was operated in scanning mode using an electron ionization voltage of $70 \mathrm{eV}$ and a mass range of $45-600 \mathrm{~m} / \mathrm{z}$.

The identification of compounds was performed using the calculated retention indexes, ${ }^{29}$ and a mixture of linear alkanes $\left(\mathrm{C}_{14}-\mathrm{C}_{36}\right.$, Sigma Aldrich, purity $\left.\geq 90 \%\right)$. The retention indexes were compared to literature values, ${ }^{4,30,31}$ and the mass spectra obtained were compared with NIST21 and WILEY229 databases.

Relative area percent for each chromatographic peak was employed as abundance approach to evaluate the contribution of each compound area to the total area, and for comparisons between samples. The sum of all peak areas was considered a $100 \%$ of each sample, and each peak was assigned a percentage corresponding to its area.

\section{Results and discussion}

The chromatographic analyses of developmental stages (egg, larval instars, pupa and adult) and nest resulted in the identification of 109 compounds (Table 1). The results of the triplicate showed variation coefficient between $3-5 \%$ indicating low discrepancy of the data. It was possible to identify 15 compounds for the eggs, 19 for the first instar larvae, 26 for the fifth instar larvae, 43 for the pupae, and 63 for the adults. Therefore, the profile became more complex, i.e., with higher number of compounds, during the progressive developmental stages.

The immature individuals presented higher levels and greater number of compounds with low molecular mass, compared to the adults (Table 1; Figure 1). These results corroborate an earlier study with colonies of Polistes annularis (Linnaeus, 1763), in which it was observed that considering the number of compounds the chemical profile became more complex from the eggs to the adult stages. ${ }^{13}$ Analysis of nest material identified 104 compounds, most of which were present at the different stages of development (Table 1; Figure 1a). 
Table 1. Relative area (\%) of compounds identified in different developmental stages and nest of Mischocyttarus consimilis

\begin{tabular}{|c|c|c|c|c|c|c|c|c|c|}
\hline \multirow[t]{2}{*}{$\mathbf{R T}^{*}$} & CRI* & $\Delta \mathrm{KI} *$ & Compounds & Egg & $\begin{array}{l}\text { Larvae } \\
\left(1^{\circ} \text { instar }\right)\end{array}$ & $\begin{array}{l}\text { Larvae } \\
\text { (5instar) }\end{array}$ & Pupae & Female & Nest \\
\hline & & \multicolumn{8}{|c|}{ Relative area (\%) } \\
\hline 6.329 & 1600 & 0 & $n-C 16$ & 1.26 & 1.14 & 0.53 & 0.10 & 0.02 & 0.01 \\
\hline 8.325 & 1700 & 0 & $n-C 17$ & 2.28 & 1.49 & 0.83 & 0.11 & 0.03 & 0.01 \\
\hline 10.665 & 1801 & 1 & $n-C 18$ & 3.62 & 1.88 & 0.6 & 0.13 & 0.06 & 0.02 \\
\hline 11.875 & 1848 & 0 & 6-MeC18 & - & - & - & - & - & 0.01 \\
\hline 12.566 & 1876 & 1 & 3-MeC18 & 3.30 & 1.87 & 0.49 & 0.48 & 0.03 & 0.05 \\
\hline 13.239 & 1901 & 1 & $n-C 19$ & 4.19 & 1.45 & 0.5 & - & 0.06 & 0.01 \\
\hline 14.273 & 1942 & 2 & 7-;10-MeC19 & - & - & - & - & - & 0.01 \\
\hline 14.776 & 1962 & 4 & 2-MeC19 & - & - & - & - & - & 0.35 \\
\hline 15.752 & 2000 & 0 & $n-C 20$ & 4.21 & 2.59 & 0.54 & 0.2 & 0.09 & 0.01 \\
\hline 18.492 & 2098 & 0 & C21:10 & - & - & - & - & - & 0.02 \\
\hline 18.523 & 2101 & 1 & $n-C 21$ & 4.58 & 1.96 & 0.63 & 0.27 & 0.09 & 0.16 \\
\hline 19.585 & 2139 & 2 & 9-MeC21 & - & - & - & - & - & 0.05 \\
\hline 20.042 & 2156 & 0 & 4-MeC21 & - & - & - & - & - & 0.01 \\
\hline 20.305 & 2167 & 1 & $2-\mathrm{MeC} 21$ & - & - & - & - & - & 0.06 \\
\hline 20.726 & 2182 & 2 & $\mathrm{MeC} 16 \mathrm{COOH}$ & - & - & - & - & - & 0.01 \\
\hline 21.276 & 2202 & 2 & $n-C 22$ & - & - & - & - & - & 0.05 \\
\hline 23.264 & 2277 & 2 & $C 23: 1$ & - & - & - & - & - & 0.01 \\
\hline 23.901 & 2300 & 0 & $n-C 23$ & 5.08 & 3.08 & 0.73 & 0.87 & 0.18 & 0.91 \\
\hline 24.894 & 2338 & 3 & 11-;9-MeC23 & - & - & - & - & - & 0.12 \\
\hline 25.008 & 2343 & 2 & 7-MeC23 & - & - & - & - & - & 0.01 \\
\hline 25.832 & 2374 & 2 & 3-MeC23 & - & - & - & - & - & 0.02 \\
\hline 26.415 & 2396 & 0 & C24:1 & - & - & - & - & - & 0.01 \\
\hline 26.517 & 2400 & 0 & $n-C 24$ & 5.45 & 4.42 & 0.58 & 0.33 & 0.09 & 0.08 \\
\hline 27.290 & 2431 & 3 & 10-;12-MeC24 & - & - & - & - & - & 0.01 \\
\hline 27.432 & 2437 & 3 & 8-MeC24 & - & - & - & - & - & 0.01 \\
\hline 28.083 & 2462 & 3 & 2-MeC24 & - & - & - & - & - & 0.05 \\
\hline 28.442 & 2476 & 3 & 3-MeC24;7- C25:1 & - & - & - & - & - & 0.01 \\
\hline 29.051 & 2500 & 0 & $n-C 25$ & 4.88 & 4.55 & 0.59 & 2.1 & 0.43 & 1.40 \\
\hline 29.939 & 2535 & 0 & $\begin{array}{l}\text { 7-;9-;11-;13- } \\
\text { MeC25 }\end{array}$ & - & - & - & - & 0.06 & 0.12 \\
\hline 29.982 & 2537 & 3 & 7-MeC25 & - & - & - & - & - & 0.02 \\
\hline 30.115 & 2542 & 2 & 6-MeC25 & - & - & - & - & - & 0.01 \\
\hline 30.285 & 2551 & 1 & 5-MeC25 & - & - & - & - & - & 0.03 \\
\hline 30.393 & 2555 & 1 & 4-MeC25 & 14.55 & 3.81 & 1.67 & 0.43 & 0.07 & 0.04 \\
\hline 30.831 & 2573 & 0 & 3-MeC25 & - & - & - & - & 0.07 & 0.11 \\
\hline 31.068 & 2582 & 0 & $\begin{array}{c}5,9-; 5,11-; 5,13- \\
\text { diMec25 }\end{array}$ & - & - & - & - & - & 0.01 \\
\hline 31.495 & 2600 & 0 & $n-C 26$ & 5.37 & 4.2 & 0.87 & 0.3 & 0.19 & 0.31 \\
\hline 31.702 & 2608 & 0 & 3,11-diMeC25 & - & - & - & - & 0.02 & 0.03 \\
\hline
\end{tabular}




\begin{tabular}{|c|c|c|c|c|c|c|c|c|c|}
\hline 32.332 & 2635 & 4 & 12-;11-MeC26 & - & - & - & - & - & 0.06 \\
\hline 32.724 & 2651 & 0 & 5-MeC26 & - & - & - & - & - & 0.01 \\
\hline 32.889 & 2658 & 0 & 4-MeC26 & - & - & - & - & - & $0 .($ \\
\hline 33.260 & 2673 & 0 & Z-9-C27:1 & - & - & - & - & 0.12 & 0.0 \\
\hline 33.889 & 2699 & 1 & $n-C 27$ & 5.82 & 7.93 & 4.62 & 4.51 & 5.12 & 5.5 \\
\hline 34.630 & 2733 & 0 & $\begin{array}{c}\text { 14-;13-;11-;9- } \\
\text { MeC27 }\end{array}$ & - & - & - & - & 0.26 & \\
\hline 34.827 & 2741 & 0 & 7- MeC27 & - & - & - & - & 0.04 & 0.3 \\
\hline 35.074 & 2751 & 0 & 5- MeC27 & - & - & - & - & 0.55 & 0.7 \\
\hline 35.365 & 2764 & 1 & $\begin{array}{l}\text { 2-MeC27;9,15- } \\
\quad \text { diMeC27 }\end{array}$ & - & - & - & - & - & \\
\hline 35.655 & 2777 & 2 & 3-MeC27 & - & - & 6.00 & 3.09 & 11.77 & \\
\hline 35.829 & 2784 & 1 & $\begin{array}{l}\text { 5,11-;5,13-;5,15- } \\
\text { diMeC27 }\end{array}$ & - & - & - & - & 0.08 & \\
\hline 36.186 & 2800 & 0 & $n-C 28$ & 5.14 & 3.97 & 1.00 & 0.82 & 1.05 & 1.2 \\
\hline 36.354 & 2807 & 0 & 3,11-diMeC27 & - & - & - & - & 0.44 & 0.2 \\
\hline 36.943 & 2833 & 0 & $\begin{array}{c}\text { 14-;13-;12-;11-;10- } \\
\text { MeC28 }\end{array}$ & - & - & - & - & - & \\
\hline 37.347 & 2851 & 4 & 4-MeC28 & - & - & - & - & 0.03 & 0.02 \\
\hline 37.489 & 2858 & 0 & 10,14-diMeC28 & - & - & - & 0.16 & 1.48 & 1.0 \\
\hline 37.773 & 2870 & 6 & 3-MeC28 & - & - & - & - & - & 0.0 \\
\hline 37.854 & 2874 & 1 & 9-C29:1 & - & - & - & 0.14 & 0.62 & 0.5 \\
\hline 37.963 & 2879 & 4 & 3-MeC28 & - & - & - & - & 0.02 & \\
\hline 38.225 & 2890 & 2 & C29:1 & - & - & - & - & 0.23 & 0.4 \\
\hline 38.432 & 2899 & 0 & $n-C 29$ & 8.04 & 16.69 & 18.91 & 18.88 & 11.28 & 9. \\
\hline 39.149 & 2933 & 0 & $\begin{array}{c}\text { 15-;13- ;11-;09- } \\
\text { MeC29 }\end{array}$ & - & - & - & - & - & \\
\hline 39.257 & 2938 & 1 & 9-MeC29 & - & - & - & 1.84 & 7.17 & 1.6 \\
\hline 39.338 & 2942 & 2 & 7-MeC29 & - & - & - & 0.53 & 0.75 & \\
\hline 39.573 & 2952 & 2 & 5-MeC29 & - & - & - & 0.23 & 0.89 & 0.7 \\
\hline 39.662 & 2956 & 2 & $\begin{array}{c}\text { 13,17-;11,15- } \\
; 9,13-\text { diMeC29 }\end{array}$ & - & - & - & - & 0.16 & \\
\hline 39.755 & 2961 & 0 & 7,11-diMeC29 & - & - & - & - & 0.61 & \\
\hline 39.965 & 2970 & 2 & 3-MeC29 & - & - & - & 0.08 & 0.08 & \\
\hline 40.074 & 2975 & 0 & $\begin{array}{l}\text { 7,17-;5,17- } \\
\text { diMec29 }\end{array}$ & - & 19.99 & 19.94 & 10.16 & 0.08 & \\
\hline 40.636 & 3001 & 1 & $n-C 30$ & - & 4.00 & 1.16 & 1.27 & 0.31 & \\
\hline 40.745 & 3007 & 4 & $\begin{array}{c}\text { 3,9-;3,11- } \\
; 3,13 ; 3,15- \\
\text { diMeC29 }\end{array}$ & - & - & 2.44 & 0.28 & 4.56 & \\
\hline 40.826 & 3010 & 0 & 3,7-diMeC29 & - & - & - & - & 0.13 & \\
\hline 41.335 & 3034 & 0 & $\begin{array}{c}\text { 15-;14-;13-;12-;11- } \\
\text { 10-MeС30 }\end{array}$ & - & - & - & 0.93 & 1.36 & \\
\hline 41.406 & 3038 & 2 & 7-;8- МeС30 & - & - & - & - & 0.31 & 0.3 \\
\hline 41.848 & 3058 & 0 & 10,14-diMeC30 & - & - & - & - & 1.15 & 0.7 \\
\hline 41.916 & 3062 & 0 & 11,20- diMeC30 & - & - & - & - & - & \\
\hline
\end{tabular}


Michelutti, K. B. et al.

\begin{tabular}{|c|c|c|c|c|c|c|c|c|c|}
\hline 41.995 & 3065 & 0 & 2-;4-МеС30 & - & - & - & - & - & 0.01 \\
\hline 42.065 & 3069 & 1 & 11-C31:1 & - & - & - & 0.1 & - & - \\
\hline 42.185 & 3074 & 4 & 3-МeC30 & - & - & - & 0.1 & 0.27 & 0.30 \\
\hline 42.485 & 3088 & 0 & C31:1 & - & - & - & 0.16 & - & - \\
\hline 42.752 & 3101 & 1 & $n-C 31$ & - & 5.07 & 9.52 & 14.64 & 2.35 & 5.92 \\
\hline 43.285 & 3128 & 2 & $\begin{array}{c}\text { 15-;13-;9-;11- } \\
\text { MeC31 }\end{array}$ & - & - & 7.52 & 12.39 & 13.04 & 4.90 \\
\hline 43.300 & 3132 & 2 & 15-;13-;11-МeС31 & - & - & - & - & - & 0.25 \\
\hline 43.446 & 3136 & 1 & 9-MeC31 & - & - & - & - & - & 0.13 \\
\hline 43.514 & 3139 & 1 & 7-MeC31 & - & - & - & 1.84 & 0.9 & 0.88 \\
\hline 43.784 & 3155 & 0 & 5-MeC31 & - & 3.7 & 3.64 & 0.36 & 12.2 & 6.91 \\
\hline 43.897 & 3158 & 0 & 4-MeC31 & - & - & - & 0.23 & 0.31 & 0.19 \\
\hline 44.084 & 3167 & 7 & $\begin{array}{l}\text { 11,15-;13,17- } \\
; 11,17-\text { ou 11,19- } \\
\text { diMeC31 }\end{array}$ & - & - & 3.5 & 5.53 & 0.92 & 2.18 \\
\hline 44.223 & 3174 & 1 & 3-МеС31 & - & - & 2.11 & 1.45 & 1.12 & 0.82 \\
\hline 44.796 & 3203 & 3 & n-C32 & - & - & 2.02 & 0.48 & 3.82 & 5.40 \\
\hline 45.265 & 3225 & 3 & 10-MeC32 & - & - & 7.14 & - & 1.57 & 2.99 \\
\hline 45.554 & 3239 & 1 & 8-MeC32 & - & - & - & - & 0.25 & 0.12 \\
\hline 45.853 & 3254 & 0 & 2-MeC32 & - & - & - & - & - & 0.14 \\
\hline 46.094 & 3265 & 0 & 4-MeC32 & - & - & - & - & - & 0.39 \\
\hline 46.286 & 3275 & 4 & 3-MeC32 & - & - & - & 1.03 & 0.12 & 0.94 \\
\hline 46.803 & 3302 & 0 & $n-C 33$ & - & - & - & 0.34 & 3.25 & 0.04 \\
\hline 47.366 & 3330 & 0 & $\begin{array}{c}\text { 15-;13-;11-;17- } \\
\text { МеС33 }\end{array}$ & - & - & - & 7.44 & 0.07 & 1.35 \\
\hline 47.452 & 3335 & 3 & 13-;15-МeС33 & - & - & - & - & 0.80 & 0.17 \\
\hline 47.605 & 3343 & 0 & $\begin{array}{l}\text { 7-MeC33 } \\
\text { 11,21- }\end{array}$ & - & - & - & - & - & 0.10 \\
\hline 47.843 & 3356 & 0 & $\begin{array}{l}; 13,19 ; 11,15- \\
\text { diMeC33 }\end{array}$ & - & - & - & - & - & 0.33 \\
\hline 48.028 & 3367 & 1 & 13,17-diMeC33 & - & - & - & 0.21 & 0.21 & 1.1 \\
\hline 48.356 & 3384 & 4 & 5,17-diMeC33 & - & - & - & - & - & 0.17 \\
\hline 48.585 & 3400 & 3 & $n-C 34$ & - & - & - & 0.53 & 0.64 & 0.63 \\
\hline 48.692 & 3405 & 5 & 3,7-;3,9-diMeС33 & - & - & - & - & - & 0.02 \\
\hline 49.043 & 3421 & 4 & $\begin{array}{c}\text { 8-;13-;15-;17- } \\
\text { MeC34 }\end{array}$ & - & - & - & 0.38 & 0.16 & 1.60 \\
\hline 49.875 & 3466 & 1 & 4-MeC34 & - & - & - & - & - & 0.09 \\
\hline 50.486 & 3498 & 2 & $n-C 35$ & - & - & - & - & 0.21 & 0.47 \\
\hline 51.149 & 3530 & 0 & $\begin{array}{c}\text { 17-;15-;13-;11- } \\
\text { МeC35 }\end{array}$ & - & - & - & - & - & 0.03 \\
\hline 51.469 & 3546 & 6 & 7-MeC35 & - & - & - & 1.3 & - & 0.44 \\
\hline 51.619 & 3553 & 1 & $\begin{array}{l}\text { 13,17-;13,21- } \\
\text { diMec35 }\end{array}$ & - & - & - & - & 0.13 & 0.30 \\
\hline 51.862 & 3564 & 2 & $\begin{array}{c}\text { 13,19-;11,17- } \\
; 11,19-\text { diMeC35 }\end{array}$ & - & - & - & - & - & 0.19 \\
\hline
\end{tabular}


- =not detected; $\mathrm{C}=$ carbon; $n=$ Linear Alkane; Me=Methyl; DiMe=Dimethyl; ${ }^{*} \mathrm{Rt}=$ Retention Time; ${ }^{*} \mathrm{CRI}=$ Calculated Retention Index; ${ }^{*} \Delta \mathrm{KI}=$ Difference between calculated and literature index.

Differences in number and level of compounds were also described between immature stages and adults of Solenopsis invicta (Buren, 1972) and Solenopsis richteri (Forel, 1909). ${ }^{32}$ In $P$. dominula it was identified a particular chemical signature for each of the different developmental stages and that immature stages had higher concentration and greater number of low molecular weight compounds, compared to the adults. ${ }^{10}$ However, it was reported that the cuticular hydrocarbon composition was similar for the last instar larvae and the newly emerged adults of $V$. germanica, and differences were only identified in the amount of some of the compounds. ${ }^{4}$

Considering the different developmental stages and nest, the identified compounds included 20 linear alkanes, 9 alkenes, 79 branched alkanes (methyl and dimethyl alkanes) and one fatty acid (Figure. 1; Table 1). In a previous study, it was not identified any alkene in the eggs, larvae, adults, and nests of $P$. annularis. ${ }^{13}$ However, linear alkanes, methyl alkanes, dimethyl alkanes, and alkenes have been found in the cuticle of larvae and adults of Polistes fuscatus. ${ }^{9}$ The same compound classes have also been identified in the cuticle of flies. ${ }^{33,34}$
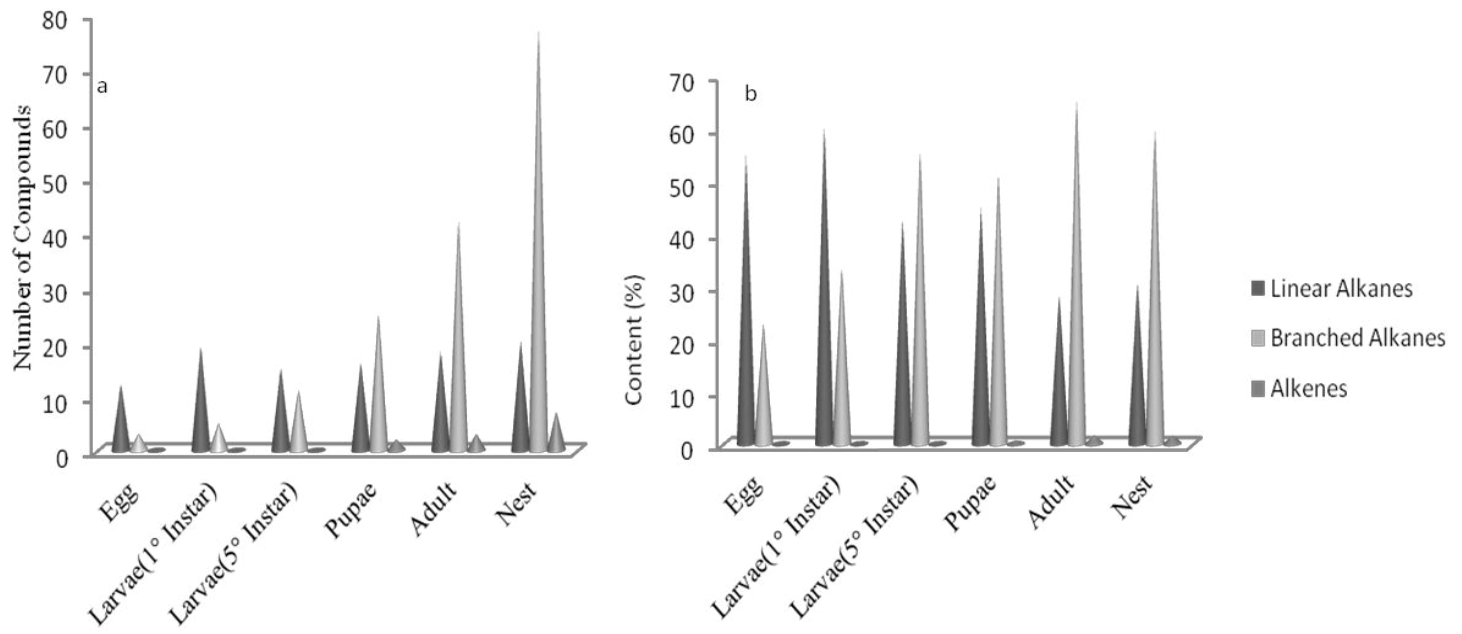

Figure 1. Number of compounds (a) and level of functional groups (b) in the cuticle of different developmental stages and nest of Mischocyttarus consimilis

The branched alkanes $3-\mathrm{MeC}_{18}, 4-\mathrm{MeC}_{25}$, and 3,7-diMeC $\mathrm{C}_{27}$, together with the linear alkanes $n-\mathrm{C}_{16}, n-\mathrm{C}_{17}, n-\mathrm{C}_{18}, n-\mathrm{C}_{20}, n-\mathrm{C}_{21}, n-\mathrm{C}_{23}$, $n-C_{24}, n-C_{25}, n-C_{26}, n-C_{27}$, and $n-C_{29}$, were found in all developmental stages and nest (Table 1). It is therefore reasonable to suppose that these compounds are the most important to compose the colony signature of this species. ${ }^{35,36}$
There was a gradual decrease in number and content of linear alkanes as the developmental stages progressed, while the opposite occurred with branched alkanes (Figure 1). These trends could indicate an alternation in the importance of these different classes of compounds as recognition signals and/or for protection against 
dehydration during the different stages of development. $^{37}$

Similarly, the study regarding cuticular chemical compounds in $P$. dominula colonies, identified the highest levels of linear alkanes in larvae and the highest levels of branched alkanes in adults. ${ }^{10}$ The same compositional variation is found in the different stages of two ant species, S. richteri and S. invicta, and it was suggested that the higher contents of linear alkanes in the sclerotized immature stages could be a strategy to prevent desiccation. ${ }^{31}$ Epicuticular linear alkanes are believed to be the hydrocarbons that provide the cuticle with waterproofing, because of their high melting points. ${ }^{37}$

The increased concentration of branched alkanes could be due to greater synthesis of these compounds in the last stages of development and/or a selective metabolism of $n$-alkanes by the adult insects. ${ }^{32}$ Several studies have suggested that branched alkanes have an important function as recognition signals. ${ }^{7,31,38}$ However, other studies have reported the importance of $n$ alkanes in this role. ${ }^{39,40}$

The results showed that all compounds present in eggs were also found in larvae and all compounds present in larvae were also found in adults (Table 1). Indeed, the cuticular hydrocarbons identified in $P$. fuscatus larvae were also present in adults, but at higher levels. ${ }^{9}$

The cuticular hydrocarbons present at the highest concentrations were $4-\mathrm{MeC}_{25}$ (eggs), 7,17-diMeC 29 (first instar larvae), 5,17diMeC $_{29}$ (last instar larvae), $n-C_{29}$ (pupae), 15 , 13-, 9-, and $11-\mathrm{MeC}_{31}$ (adults), and $n-\mathrm{C}_{29}$ (nest) (Table 1). These results are similar to those obtained in others studies, which identified high $n-C_{29}$ levels in the pupal stage of $V$. germanica, ${ }^{4}$ and analyzed the chemical composition of six species of fly and found that $n-C_{27}$ and $n-C_{29}$ alkanes were present at high concentrations. ${ }^{33}$ However, in a study with $P$. annularis wasp, ${ }^{13}$ it was reported that the compounds present at highest concentrations were $3-\mathrm{MeC}_{29}$ (eggs), 13- or
$15-\mathrm{MeC}_{29}$ (larvae), and 13,17-diMeC 31 (adults).

Compounds that are especially prevalent in specific stages can serve as markers of these stages, hence enabling their identification by nestmates in the colony. ${ }^{8,9}$

Variations in number of $n$-alkanes $\left(n-C_{16}\right.$ to $n-C_{35}$ ) were found for all stages of development and nest, with linear alkanes $n$ $\mathrm{C}_{27}$ and $n-\mathrm{C}_{29}$ generally present at higher concentrations (Figure 1b; Table 1). Also, it was observed higher levels of the linear alkanes $n-C_{27}$ and $n-C_{29}$ in adults and nest of Polistes metricus. ${ }^{20}$

All alkenes occurred at lower levels and it was possible to identify nine compounds: $\mathrm{C}_{21: 1}, \mathrm{C}_{23: 1}, \mathrm{C}_{24: 1}, \mathrm{C}_{25: 1}, 9-\mathrm{MeC}_{27: 1}, \mathrm{C}_{29: 1}, \mathrm{C}_{31: 1}, 9-$ $\mathrm{MeC}_{29: 1}$, and 11-MeC $\mathrm{C}_{31: 1}$. The first three were only present in the nest, while the others were present in adults and pupae (Figure $1 \mathrm{~b}$; Table 1). Differently from our results, alkenes were present in larvae of $P$. dominula ${ }^{41}$ In studies with adults of $P$. fuscatus ${ }^{43}$ and Polistes satan (Bequaert, 1940), ${ }^{42}$ alkenes were also the least representative compounds. However, considering the informational contents of the compound classes, it is known that linear alkanes can only vary in chain length, while alkenes can vary in number and position of the double bonds, and branched alkanes can vary in number of branches, their molecular position, and optical configuration, therefore, branched alkanes are more likely to possess informational content. ${ }^{44}$ Alkenes were also described as important for intraspecific discrimination $\ln P$. dominula. ${ }^{45}$

Another important finding was the presence of $\mathrm{MeC}_{16} \mathrm{COOH}$ in nest material (Table 1$).{ }^{13}$ In a study with the species $P$. annularis, this compound was only found in the nest's peduncle. The authors suggested that this fatty acid might be partly responsible for repelling ants, and could therefore contribute to defending the colony against invasion. However, for this species, repellent substances were apparently not restricted to the peduncle, but found throughout the nest. 
The nest material contained a greater number of compounds, compared to the colony (Figure 1; Table 1). There was similarity between the contents of functional groups of nest material and adults (Figure $1 \mathrm{~b}$; Table 1), probably due to the interactions among the latter. ${ }^{38}$ Similar findings have been reported for colonies of $P$. metricus $($ Say, 1831$){ }^{20}$ V. germanica, ${ }^{4}$ and $P$. dominula. ${ }^{10}$

The relationship observed between nest's compounds and those of the individuals of the colony (mainly adults) could also be associated with the transference of substances from some glands (especially by saliva) into the nest during its formation, hence impregnating it with their own compounds, as described in colonies of $P$. annularis. ${ }^{13}$ Therefore, compounds present in the epicuticular surface of the insects are acquired from the nest material, and viceversa. ${ }^{18}$ This is also a consequence of the substantial addition of chemical substances into the nest by the adults, ${ }^{10}$ as well as the interactions among the adults themselves. ${ }^{13}$ However, recent studies with $P$. dominula showed that in the early hours of emergence, when subjected to contact with alien nests, the ability of the pupal stage and adults to recognize nestmates was not affected; they were still able to discriminate between nestmates and non-nestmates. ${ }^{21,22}$ Nonetheless, emphasis was placed on the importance of the nest for recognition among individuals of the same colony, possibly at other times during the insect's life. ${ }^{21,22}$ It is therefore clear that the colony signature is a mixture of all compounds present in the individuals and also in the nest. ${ }^{38}$

\section{Conclusions}

The results lead to the conclusion that the different developmental stages and the nest had particular chemical profiles, and that during the progressive development of the stages there was a reduction in the number and content of linear alkanes and an increase in the number and content of branched alkanes. These changes could be explained by the roles played by the different compound classes during each stage. The nest was more complex regarding the number of compounds than the colony's members, although the level of the compound classes were similar to those of the adults, probably due to the wasps' behavior, since nest construction results in the incorporation of compounds derived from the sources of the raw materials as well as from interactions among the colony's individuals and their nests.

\section{Acknowledgments}

The authors thank Fundação de Apoio ao Desenvolvimento do Ensino, Ciência e Tecnologia do Estado de Mato Grosso do Sul (FUNDECT); Coordenação de Aperfeiçoamento de Pessoal de Nível Superior (CAPES) for providing a Masters fellowship to the fisrt author; authors WFAJ and CALC acknowledge research grants from Conselho Nacional de Desenvolvimento Científico e Tecnológico (CNPq).

\section{References}

${ }^{1}$ Singer, T. L. Roles of hydrocarbons in the recognition systems of insects. American Zoologist 1998, 38, 394. [CrossRef]

${ }^{2}$ Lockey, K. H. Lipids of the insect cuticle: Origin, composition and function. Comparative Biochemistry and Physiology 1988, 89B, 595. [CrossRef]

${ }^{3}$ Howard, R. W.; Blomquist, G. J. Ecological, behavioral, and biochemical aspects of insect hydrocarbons. Annual Review of Entomology 2005, 50, 371. [CrossRef] [PubMed]

${ }^{4}$ Brown, W. V.; Spradbery, J. P.; Lacey, M. J. Changes in the cuticular hydrocarbon composition during development of the social wasp, Vespula germanica (f.) 
(Hymenoptera: Vespidae). Comparative Biochemistry and Physiology 1991, 99, 553. [CrossRef]

${ }^{5}$ Borges, A. A.; Ferreira-Caliman, M. J.; Nascimento, F. S.; Campos, L. A. O.; Tavares, M. G.; Characterization of cuticular hydrocarbons of diploid and haploid males, workers and queens of the stingless bee Melipona quadrifasciata. Insectes Sociaux 2012, 59, 479. [CrossRef]

${ }^{6}$ Hölldobler, B.; Wilson E. O. The Ants. Belknap Press, Cambridge, Mass. pp. 732, 1990. [CrossRef]

${ }^{7}$ Blomquist, G. J.; Bagnéres, A. G. Insect hydrocarbons biology, biochemistry, and chemical ecology. Published in the United States of America by Cambridge University Press, New York. pp 492, 2010.

${ }^{8}$ Klahn, J. E.; Gamboa, G. J. Social Wasps: Discrimination Between Kin and Nonkin Brood. Science 1983, 221, 482. [CrossRef] [PubMed]

${ }^{9}$ Panek, L. M.; Gamboa, G. J. Queens of the Paper Wasp Polistes fuscatus (Hymenoptera: Vespidae) Discriminate among larvae on the basis of relatedness. Ethology 2000, 106, 159. [CrossRef]

${ }^{10}$ Cotoneschi, C.; Dani, F. R.; Cervo, R.; Sledge, M. F.; Turillazzi, S. Polistes dominulus (Hymenoptera: Vespidae) larvae possess their own chemical signatures. Journal of Insect Physiology 2007, 53, 954. [CrossRef] [PubMed]

${ }^{11}$ Dapporto, L.; Theodora, P.; Spacchini, C.; Pieraccini, G.; Turillazzi, S. Rank and epicuticular hydrocarbons in different populations of the paper wasp Polistes dominulus (Christ) (Hymenoptera, Vespidae). Insect Sociaux 2004a, 51, 279. [CrossRef]

${ }^{12}$ Dapporto, L.; Palagi, E.; Turillazzi, S. Epicuticular hydrocarbons of Polistes dominulus as a biogeographic tool: a study of populations from the tuscan archipelago and surrounding areas. Journal of Chemical Ecology 2004b, 30, 2139. [CrossRef] [PubMed]

${ }^{13}$ Espelie, K. E.; Hermann, H. R. Surface lipids of the social wasp Polistes annularis (L.) and its nest and nest pedicel. Journal of Chemical Ecology 1990, 16, 1841. [CrossRef] [PubMed]
${ }^{14}$ Downing, H. A. In: The function and evolution of exocrine glands. Ross, K. G., Matthews, R. W., eds.; The Social Biology of Wasps. Ithaca and London: Comstock Publ. Ass. pp. 540-569, 1991. [CrossRef]

${ }^{15}$ Bonckaert, W.; Drijfhout, F. P.; D'ettorre, P.; Billen, J.; Wenseleers, T. Hydrocarbon signatures of egg maternity, caste membership and reproductive status in the common wasp. Journal of Chemical Ecology 2012, 38, 42. [CrossRef] [PubMed]

${ }^{16}$ Billen, J. A importância das glândulas exócrinas na sociedade de insetos. In: Vilela, E.; Vilela, E. F.; Santos, I. A.; Schoereder, J. H.; Serrão, J. E.; Campos, L. A. O.; Lino-Neto, J. (Eds.). Insetos Sociais: $\mathrm{Da}$ biologia à aplicação. Viçosa, Minas Gerais: Editora UFV. pp. 442, 2008. [Link]

${ }^{17}$ Neves, E. F.; Andrade, L. H. C.; Súarez, Y. R.; Lima, S. M.; Antonialli-Junior, W. F. Agerelated changes in the surface pheromones of the wasp Mischocyttarus consimilis (Hymenoptera: Vespidae). Genetics and Molecular Research 2012, 11, 1891. [CrossRef] [PubMed]

${ }^{18}$ Singer, T. L.; Espelie, K. E. Social wasps use nest paper hydrocarbons for nestmate recognition. Animal Behaviour 1992, 44, 63. [CrossRef]

${ }^{19}$ Sumana, A.; Liebert, A. E.; Berry, A. S.; Switz, G. T.; Orians, C. M.; Starks, P. T. Nest hydrocarbons as cues for philopatry in a paper wasp. Ethology 2005, 111, 469. [CrossRef]

${ }^{20}$ Espelie, K. E.; Wenzel, J. W.; Chang, G. Surface lipids of social wasp Polistes metricus say and its nest and nest pedicel and their relation to nestmate recognition. Journal of Chemical Ecology 1990, 16, 2229. [CrossRef] [PubMed]

${ }^{21}$ Signorotti, L.; Cappa, F.; d'Ettorre, P.; Cervo, R. Novel insights into the ontogeny of nestmate recognition in polistes social wasps. Plos One 2014, 9, 1. [CrossRef] [PubMed]

${ }^{22}$ Signorotti, L.; d'Ettorre, P.; Sguanci, G.; Cervo, R. Pupal experience and nestmate recognition in Polistes dominula wasps. Insectes Sociaux 2015, 62, 433. [CrossRef]

${ }^{23}$ Richards, O. W. The social wasps of the Americas, excluding the Vespinae. London, 
British Museon (Natural History). pp. 580, 1978. [Link]

${ }^{24}$ Montagna, T. S.; Torres, V. O.; Dutra, C. C.; Suarez, Y. R.; Antonialli-Junior, W. F.; AlvesJunior, V. V. Study of the foraging activity of Mischocyttarus consimilis (Hymenoptera: Vespidae). Sociobiology 2009, 53, 131. [Link]

${ }^{25}$ Torres, V. O.; Montagna, T. S.; Fernandes, W. D.; Antonialli-Junior, W. F. Colony cycle of the social wasp Mischocyttarus consimilis Zikán (Hymenoptera, Vespidae). Revista Brasileira de Entomologia 2011, 55, 247. [CrossRef]

${ }^{26}$ Montagna, T. S.; Raizer J.; AntonialliJunior, W. F. Effect of Larval Topical Application of Juvenile Hormone on Caste Determination in the Independent-Founding Eusocial Wasp Mischocyttarus consimilis (Hymenoptera: Vespidae). Open Journal of Animal Sciences 2015, 5, 174. [CrossRef]

${ }^{27}$ Parra, J. R. P.; Haddad, M. L. Determinação do número de instares de insetos. Piracicaba: FEALQ. pp. 49, 1989. [Link]

${ }^{28}$ Silva, E. R. S.; Michelutti, K. B.; AntonialliJunior, W. F.; Batistote, M.; Cardoso, C. A. L. Chemical signatures in the developmental stages of Protopolybia exigua. Genetics and Molecular Research 2016, 15, 1. [CrossRef] [PubMed]

${ }^{29}$ Van den Dool, H.; Kratz, P. D. A generalization of the retention index system including linear temperature programmed gas-liquid partition chromatography. Journal of Chromatography 1963, 11, 463. [CrossRef] [PubMed]

${ }^{30}{ }^{30}$ Grunshaw, J. P.; Guermouche, H.; Guermouche, S.; Jago, N. D.; Jullien, R.; Knowles, E.; Perez, F. Chemical taxonomic studies of cuticular hydrocarbons in Polistes cuticular hydrocarbons 679 Locusts of the Schistocerca americana complex: chemical relationships between new world and old world species. Journal of Chemical Ecology 1990, 16, 2835. [CrossRef]

${ }^{31}$ Bonavita-Cougourdan, A.; Theraulaz, G.; Bagnéres, A. G.; Roux, M.; Pratte, M.; Provost, E.; Clément, J. L. Cuticular hydrocarbons, social organization and ovarian development in a polistine wasp: polistes dominulus christ. Comparative
Biochemistry and Physiology 1991, 100B, 667. [CrossRef]

${ }^{32}$ Lok, J. B.; Cupp, E. W.; Blomquist, G. J. Cuticular lipids of the imported fire ants, Solenopsis invicta and richteri. Insect Biochemistry and Molecular Biology 1975, 5, 821. [CrossRef]

${ }^{33}$ Ye, G.; Li, K.; Zhu, J.; Zhu, G.; Hu, C. Cuticular hydrocarbon composition in pupal exuviae for taxonomic differentiation of six necrophagous flies. Annals of the Entomological Society of America 2007, 44, 450. [CrossRef] [PubMed]

${ }^{34}$ Yoon, C.; Yang, J. O; Youn, Y. N.; Kim, G. H. Changes in cuticular hydrocarbons in different developmental stages of the bean bug, Riptortus pedestris (Hemiptera: Alydidae). Journal of Asia-Pacific Entomology 2012, 15, 579. [CrossRef]

${ }^{35}$ Baracchi, D.; Dapporto, L.; Tesseo, S.; Hashim, R.; Turillazzi, S. Medium molecular weight polar substance of the cuticle as tools in the study of the taxonomy, systematics and chemical ecology of tropical hover wasps (Hymenoptera: Stenogastrinae). Journal of Zoological Systematics and Evolutionary Research 2010, 48, 109. [CrossRef]

${ }^{36}$ Khidr, S. K.; Linforth, R. S. T.; Hardy, I. C. W. Genetic and environmental influences on the cuticular hydrocarbon profiles of Goniozus wasps. Entomologia Experimentalis et Applicata 2013, 147, 175. [CrossRef]

${ }^{37}$ Gibbs, A. G. Water-proofing properties of cuticular lipids. American Zoologist 1998, 38, 471. [CrossRef]

${ }^{38}$ Lorenzi, M. C.; Azzani, L.; Bagnères, A. G. Evolutionary consequences of deception: Complexity and informational content of colony signature are favored by social parasitism. Current Zoology 2014, 60, 137. [Link]

${ }^{39}$ Lorenzi, M. C.; Sledge, M. F.; Laiolo, P.; Sturlini, E.; Turillazzi, S. Cuticular hydrocarbon dynamics in young adult Polistes dominulus (Hymenoptera: Vespidae) and the role of linear hydrocarbons in nestmate recognition systems. Journal of Insect Physiology 2004, 50, 935. [CrossRef] [PubMed]

${ }^{40}$ Ferreira, A. C.; Cardoso, C. A. L.; Neves, E. F.; Súarez, Y. R.; Antonialli-Junior, W. F. 
Distinct linear hydrocarbon profiles and chemical strategy of facultative parasitism among Mischocyttarus wasps. Genetics and Molecular Research 2012, 11, 4351. [CrossRef] [PubMed]

${ }^{41}$ Cotoneschi, C.; Dani, F. R.; Cervo, R.; Scala, C.; Strassmann, J. E.; Queller, D. C.; Turillazzi S. Polistes dominulus (Hymenoptera, Vespidae) larvae show different cuticular patterns according to their sex: workers seem not use this chemical information. Chemical Senses Journal 2009, 34, 195. [CrossRef] [PubMed]

${ }^{42}$ Tannure-Nascimento, I. C.; Nascimento, F. S.; Turatti, I. C.; Lopes, N. P.; Trigo, J. R.; Zucchi, R. Colony membership is reflected by variations in cuticular hydrocarbon profile in a Neotropical paper wasp, Polistes satan (Hymenoptera, Vespidae). Genetics and
Molecular Research 2007, 6, 390. [CrossRef] [PubMed]

${ }^{43}$ Espelie, K. E.; Gamboa, G. J.; Grudzien, T. A.; Bura, E. A. Cuticular hydrocarbons of the paper wasp, Polistes fuscatus: a search for recognition pheromones. Journal of Chemical Ecology 1994, 20, 1677. [CrossRef] [PubMed] ${ }^{44}$ Hefetz, A. The evolution of hydrocarbon pheromone parsimony in ants (Hymenoptera: Formicidae) - interplay of colony odor uniformity and odor idiosyncrasy. A review. Myrmecological News 2007, 10, 59. [Link]

${ }^{45}$ Dapporto, L.; Sledge, F. M.; Turillazzi, S. Dynamics of cuticular chemical profiles of Polistes dominulus workers in orphaned nests (Hymenoptera, Vespidae). Journal of Insect Physiology 2005, 51, 969. [CrossRef] [PubMed] 